\title{
Developing Web-Based Teaching Material Supplements To Improve Higher Order Thinking Skills In Mathematics Courses
}

\author{
Eko Andy Purnomo ${ }^{1}$, Suparman $^{2}$, Sri Kadarwati ${ }^{3}$ \\ \{ekoandy@unimus.ac.id ${ }^{1}$, suparman@ecampus.ut.ac.id² ${ }^{2}$ skadarwati@ecampus.ut.ac.id ${ }^{3}$ \} \\ ${ }^{1}$ University of Muhammadiyah Semarang, Semarang, Central Java, Indonesia \\ 2,3 Open University, Semarang, Central Java, Indonesia
}

\begin{abstract}
The aim of Mathematics learning is providing the students to have logical, analytical, systematic, critical, and creative thinking skills, as well as ability to cooperate. One of the main capabilities of the student is the Higher Order Thinking Skills (HOTS). Based on the preliminary observation on students of PGSD UT Pokjar Kaliwungu 2018.1, there were still many students who had low HOTS, especially in mathematics course. This condition is proven from how the students solve the problems for a high level and unsual of difficulty exercises on mathematics courses which was very low. One of the efforts to increase HOTS capability is by using appropriate teaching materials supplements. The media learning is known to increase effectiveness, activity and improving the learning outcomes. Web Media is one of the learning media developed in mathematics learning. All in all, this study will develop a web-based learning ingredient supplement. The purpose of this study is to produce a valid teaching ingredient supplement that can enhance the student's HOTS ability. Besides, this research used a method of developing a device development with the theory of Thiagarajan, Semmel and Semmel known as 4-D models which consisted of four stages: define, design, develop, and disseminate. The method of collecting data applied the distribution of polls, observation in class and the legibility test followed by interviews. Based on the stage of teaching materials supplements obtained 1). The phase of the teaching ingredient supplement has been adapted to the students od Universitas Terbuka characteristics, mathematics and learning objectives, 2). On-hold design of the teaching materials supplement has been designed based on the results of definition Phase 3). Development results obtained a). The value of experts and practitioners of 3.94 with valid criteria, B). The results of small legibility tests resulted in a 3.82 assessment with categories usable with fewer revisions, c). A large legibility test results in the value of 4.12 with the category can be used without revision. Based on the results above it can be concluded that the teaching materials supplement is valid and can be implemented in the trial class.
\end{abstract}

Keywords: Higher Order Thinking Skills, Teaching Material Supplements, Thiagarajan, Web.

\section{Introduction}

Learning mathematics is the device that can be used to develop strategies or ways of thinking, because the mathematical learning process contains intellectual activities that could potentially form a person's thinking ability. A difficult cognitive problem is useful to improve brain performance and promote students in solving problems. The first ability to solve a difficult problem is the ability to use the 
prior knowledge, and the strategy used is a trial and error strategy. The fundamental characteristic required during the problem solving process can be obtained through the development of logical, critical, systematic and mathematical problem solving skills. So, students are required to use their optimal thinking skills. One of the capabilities in mathematics is the Higher Order Thinking your (HOTS). Thus, it is necessary to design a learning that can lead students to HOTS capabilities. Therefore, lecturers in addition to mastering the competence of the field of science must also master various methods/models of learning and matters related to technology innovations.

Technological advances have shifted the paradigm of learning systems that are from paradigms that focus on "teaching" to be centered on "learning". A paradigm centered on learning aims at achieving objectives in order to prepare students as human beings who can study independently learners. Nowadays, it has been designed to help students understand the material in the course of the study. The self-contained learning Web is composed of elements that combine several components such as color, text, animations, images/graphics, sound, and video, photography, sound, and data controlled with computer programs in one software Digital. Moreover, based on the research conducted, there are more than $40 \%$ of students use the Internet every day to get information, games, and social network [1]. Thus, it is necessary to implement a Web-based learning medium in mathematics courses.

The Mathematics Course (PDGK4108) is a required subject for students of the PGSD study program. This course is subject to the concepts of mathematical logic; reasoning and mathematical systems; inear and quadratic equations and noalities; relationships and functions; Opportunities Social arithmetic; Introduction to statistics I and II; Problem solving; Transformation and congruity and construction [2]. The main purpose of mathematics is the students can implement the material in everyday life. One of the skills which must be achieved by the students is applying materials with HOTS capabilities. The skills of HOTS students are still low which is reflected when students work on unusual problems. In addition, students are not able to apply the theory learned to daily life, especially in technology. This phenomenon is an image of the results of a relatively low mathematical course learning compared to other courses of study.

Based on the media research results is known to increase effectiveness, activity and improve learning outcomes [3]. Web is one of the learning media developed in mathematics learning. Web Media has been developed in several classes of material. Moreover, the advantage of Web Learning Media is 1). it can provide general electronic information to learners and educational content that help achieve knowledge without the blame for location and time [4], [5], the use of mobile learning can improve the motivation of learning learning Mathematics [6] The use of web-based learning media can lower the static atmosphere and can create an effective learning process, engaging, interactive and can inspire students to learn motivation [7]. The development of the learning media emphasizes on the characteristics of mathematical and distance learning courses. Increased activity and motivation of students will also influence the increasing troubleshooting capabilities [8]. In this study will develop a web-based teaching material supplement to improve student HOTS on the mathematics course.

\section{Research Method}

This research was research and development of teaching materials supplements. The devices developed include SAT, RAT, and web learning media. The development model used 4-D model of Thiagarajan, Semmel and the modified Semmel. The development Model consisted of four stages: define, design, develop, disseminate [9]. The use of development models produced a specific product by developing and testing the effectiveness of a product. The method of collecting was data through the distribution of polls, observation in class and the legibility test followed by interviews. Data collection results are analyzed and presented using descriptive statistics. 


\section{Finding and Discussion}

The development stages of the teaching materials supplement using the 4-D models of Thiagarajan, Semmel and Semmel are modified. The development Model consisted of three stages: define, design, develop. The development stages of teaching materials supplement as follows.

\section{Define}

In define stage consisted of several stages 1). Analyzing of problems and alternatives to the development of teaching materials supplements; 2). Analyzing of students' characteristics; 3 ). Analyzing of mathematics courses; 4). Determining the learning indicators; and 5). Determining learning objectives. The first stage by analyzing the problem in the implementation of Mathematics course tutorial. When tutorial was done, the activation of students was less and the motivation to follow had a low lecture. Many students were not prepared material and mastery less material. This was the impact of the final exam, some got a less value and some did not pass the course. Based on this, there was a solution to solve the problem of mathematics course.

The first step solved the problem of mathematics courses by analyzing the characteristics of UT students. UT students had mostly worked or taught in terms of teaching almost all teaching in elementary School. Because many students were already teaching the time, energy, and minds who had two duties between lecturing and teaching as teachers. Thus, there needs to be a balance between tutorial meetings and independent learning.

The mathematical courses contained the concepts of mathematical logic; reasoning and mathematical systems; Linear and quadratic equations and noalities; relationships and functions; Opportunities Social arithmetic; Introduction to statistics I and II; Problem solving; Transformation and congruity and construction [2]. Based on the results of the poll and interviews could be concluded many students had difficulties on the material equation and inequality quadratic, transformation and introduction of statistics II. The material was easily acceptable to students of mathematical logic, social arithmetic and problem solving. According to the interview, students could conclude because some of these difficulties were due to: 1). the material for the mathematics course was very much, 2). The material was not taught in elementary school so that students were not accustomed to study this material, $3)$. The material had a high level of complexity. The results of the poll and the interviews then determined the learning indicators and objectives. Learning Objectives Mathematics wass a student who could apply the material of mathematics to other courses and in everyday life day.

2. Design

After define step, the next step was designing learning media. The main teaching material supplements were developed in a Web-based mathematics learning medium. The Learning media design was adapted to the characteristics of the UT students and the characteristics of mathematical courses. It should be noted that mathematics in colleges had several different characteristics with school mathematics [10]. Such characteristics could be the difference between the algorithm, vision, social and cultural conditions of each person. The design results can be seen in Figure 1 below. 


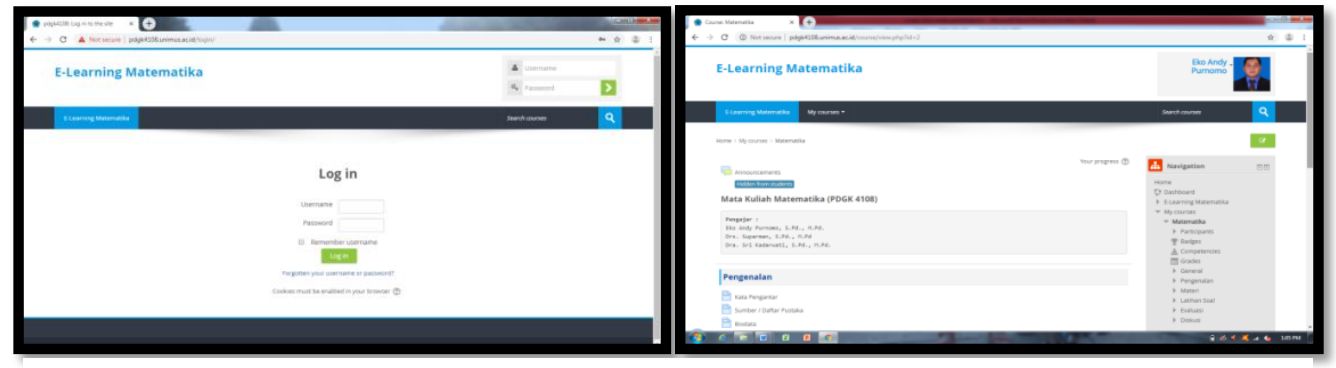

Figure 1. Mathematics Courses media

The pre design of learning media can be seen in Figure 1. Media Learning in design was as appealing as possible with combinations of colors and shapes. Every student was given a learning media account this was done so that every student activity in the learning media could be recorded in the data base. Recording of student activities could be known how many students log in, the duration of the study activities, the number of materials that had been studied, timeliness of students in the task of work, knowing the early and final skills of the student. All of these could be seen on the lecturer's account, so that the lecturer could reproduce every thing needed. Creating a menu on the learning media could be seen in Figure 2.

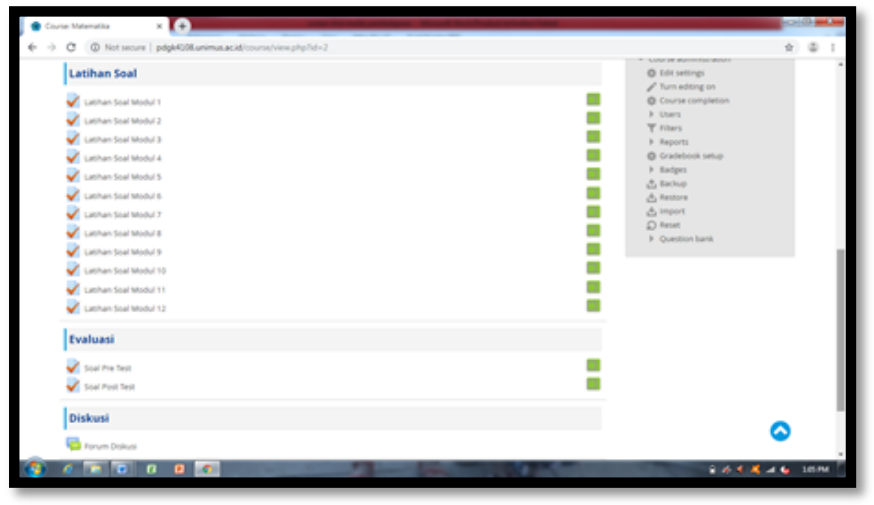

Figure 2. Creating a menu on the learning media

The main menu in the learning Media was divided into several menus including 1). An introduction consisting of a preface, a source/bibliography, and Biodata; 2). Material consisting of 12 modules; 3). Exercise problems packaged in 12 modules; 4). Evaluation consisting of pretests and postes; 5). Discussion. This introductory material included introductory mathematics, lecturers and learning media related matters. In the introduction was divided into three parts are the introduction, source/bibliography, and Biodata. On the material menu was divided into 12 modules, it was adjusted with the mathematical module of mathematics that had been used as reference during this time. Each module consisted of a summary of the material per module. With the conclusion of this material could facilitate students to 
study the material. In addition to the summary there was a concept map driven by the material learned for every module.

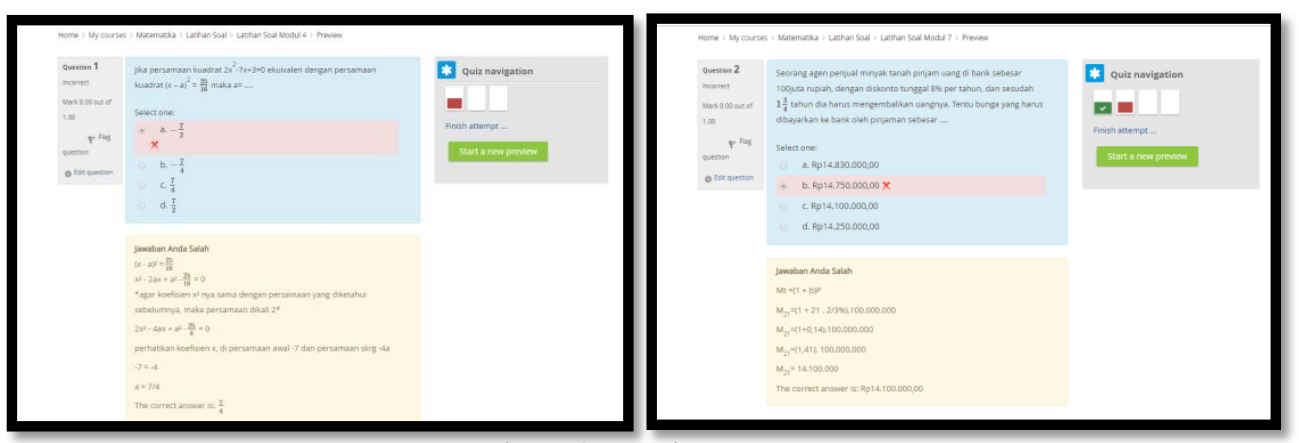

Figure 3. Practice Menu

Figure 3 displays about there were material and training menu for each module. The advantages of the training menu were divided according to the modules to facilitate students to know their abilities. Material mastery could be seen in module exercises because students would know their value. In working on the training students could find out the answer to whether it was right or wrong. If the student answers were wrong, then the student could see the correct answer and how to solve it. The evaluation consisted of pretests and postest. Pretests done students at the beginning of the tutorial, with the presence of this pretests can be known early student skills. The result of this pretests could be used as reference in the tutorial that would be implemented and could be used as a comparison of Postest. Postest used to see the results of students' tutorials. Postest was implemented at the end of the tutorial

Pretest and Postest were designed with regard to questions with the type of HOTS, the spread of questions for every module and the timing of the questions. The evaluation design was chosen about HOTS, noting the level of complexity, difficulty, and implementation of the questions. The evaluation was designed in such a way that each module had an equitable comparison. In the work of evaluation also paid attention to the time given. Work was limited to the maximum time according to needs. At the end of the work could be known how long the student was doing evaluation. The working time of the questions could be used as a reference to provide added value to the students. In addition, it could be seen recapitulation of every matter done incorrectly or correctly.

The last Menu on the learning media was discussion. This Menu was very flexible because it could be made according to your needs. Lecturers could create discussion menus based on material, modules or as needed in the tutorial. This discussion Menu contained discussion of material between lecturers and students. Lecturers could throw a problem or discussion material, then students could respond to the material that had been submitted by the lecturer. The results of this discussion were the chats that had been recorded in the data base, so it could be seen that the students are active.

\section{Develop}

Hasil perancangan media pembelajaran kemudian dilanjutkan dengan tahap pengembangan. Pada tahap pengembangan ini terdiri dari validitas ahli dan uji keterbacaan. Pada validitas ahli terdiri dari ahli media, ahli evaluasi dan ahli materi Matematika. Hasil validasi dapat dilihat pada tabel 1 di bawah ini.

The learning media design result was continued with the development stage. At this stage of development consisted of members ' validity and legibility testing. On the validity of the expert consisted of media experts, evaluation experts and expert mathematics materials. The validation resultscould be seen in Table 1. 
Table 1. Expert validation results on learning media

\begin{tabular}{|c|c|c|c|}
\hline No. & Validator & Skills/ Expertise & $\begin{array}{c}\text { Validation Results } \\
\text { AVerage }\end{array}$ \\
\hline 1 & Validator 1 & Mathematics & 3.87 \\
\hline 2 & Validator 2 & Evaluation & 4.01 \\
\hline 3 & Validator 3 & Learning media & 3.95 \\
\hline \multicolumn{3}{|c|}{ Average } & 3.94 \\
\hline \multicolumn{3}{|c|}{ Category } & Valid with slight revision \\
\hline
\end{tabular}

Based on expert validation, it can be seen that mathematics experts with a score of 3.87 had valid categories with fewer revisions. In the evaluation there were some changes related to the material. The material had not fully emphasized on the HOTS capabilities. The material that was targeted will still focus on the ability to understand mathematical concepts and communication. From the evaluation expert more emphaszed on pretests and postest, the evaluation had not been varied. The change from the variation of the problem will make the students more challenged again in working on the test. The addition of evaluation was so small that students are likely to work on the same question between pretests and postest. The evaluation expert score of 4.01 was very valid with a slight revision. The last cathedral is a learning media expert. Based on the input media experts was good, but it needed to add a little animation for the media to be more interesting. A learning media expert score of 3.95 belongs to a valid category with fewer revisions.

After validating experts, the next step was legibility test. The readability test was divided into 2 i.e. small and large-scale legibility tests. In small scale trials there were some 1 inputs. The evaluation needed to improve grammar and clarity about evaluation, 2). Needed to add a question in the Practice menu, 3). Added material on learning media. The results of small legibility tests result was 3.82 rating with valid categories that could be used with slightly revisions. The next step was large-scale legibility trials. The large legibility test results was in the value of 4.12 with highly valid categories could be used without revision. Based on the theory of development of Thiagarajan theory, Semmel and Semmel 3 phases had been implemented namely: define (defining), Design (design) The next step wass the implementation of the teaching material supplements in the tutorial.

\section{Discussion}

The development of teaching materials supplements on research is aimed to increase the ability of HOTS students.Thus, from define step already analyzed related to the cause of low student HOTS ability through consideration of student's characteristics, the characteristic of tutorials and material characteristics on the mathematics course. Through this analysis will be in the design of a learning media that is training and familiarize students in doing the problem of HOTS. Starting from the practice question, the evaluation of the pretests and postes. Through this exercise, students are expected to be more challenged to work on the problems in learning media.

This learning media is beautifully designed with a combination of color, shape and a combination of media menus. Interesting learning media design is expected to increase students ' interest in learning the material. The use of interesting web-based learning settings will lead to an interest [11] and the student's interest in learning will increase which will eventually make the student understand the material given [12]. The need to study materials is also noted and provided in a complete range of materials, 
training questions, evaluation, and discussion forums. Discussion forums are created so that among students can interact and gain more knowledge. Media learning allows for more opportunities for direct collaboration and interacts informally among students [5]. Discussion forums can also increase student understanding of learning materials [13].

In the training menu is designed so that students can work on the practice and can directly know the correct answer so that students can immediately evaluate the mistakes in doing the problem. The evaluation question was made and chosen is a question that has a high level. With this HOTS problem, students from the beginning will be accustomed to the problems with the high level. Thus, by familiarizing working on these problems will improve the ability of HOTS.

The advantages of media that has been developed is 1) very complete learning media according to the needs of students so that students can study independently; 2) Items or questions presented are a high level of problem; 3). Integrated materials allow students to gain an exciting learning experience as they are more interactive and effective; 4). Media display provides diverse combinations of colors and shapes that look attractive; 5). All student activities can be recorded in the data base and can be taken according to the needs. Lack of this learning medium 1). Training and evaluation are still very limited; 2). There is no animation and visualization in any material. Through completeness this is expected all the student needs in the tutorial activities fulfilled. This facility is expected for students to be more optimal in learning the material, so student's HOTS capability increases. Based on the analysis of media learning online media use has an impact on increasing student test results of 68\% [14]. Through the excess development of the learning materials supplement will increase the activation and motivation of students so that it will later increase the ability of student's HOTS.

\section{Conclusion}

Based on the development of teaching materials supplements results can be concluded that:

1. The development of teaching materials supplement to mathematics courses in accordance with the theory of Thiagarajan, Semmel and Semmel modified. The development Model consisted of 3 stages: define, design, and develop.

2. It produced a teaching material supplement on valid mathematical courses with a score of 3.87 valid categories with fewer revisions, small legibility test with a score of 3.82 was valid categories can be used with a slight revision, large readability test score 4.12 had very valid category which can be used without revision.

3. Based on the study of literature, it can be concluded that the teaching material supplements on mathematical courses can increase HOTS students.

\section{References}

[1] Benedict, L. and Pence, H. E. 2012. "Teaching Chemistry Using Student-Created Videos and Photo Blogs Accessed with Smartphones and Two-Dimensional Barcodes". Journal of Chemical Education, 89 (1)

[2] Sukirman dkk. 2012. Matematika. Jakarta : Universitas Terbuka

[3] Muhab, Sukro. 2009. Pengembangan Media Pembelajaran sebagai Penunjang Pembelajaran Kimia SMA. Jurnal Pendidikan Matematika dan Sains. 4.

[4] Arifpurnamayana, M. I. 2012. Rancangan dan Pembuatan Mobile Learning Berbasis Android. [Online]. Diakses pada http://repository.gunadarma.ac.id.

[5] Fatmawati, S. 2015. Pengembangan Mobile Learning Berbasis Android Menggunakan Adobe Flash CS6 Pada Mata Pelajaran Bahasa Inggris Untuk Meningkatkan Hasil Belajar Siswa Kelas X TKJ SMK Hidayah Semarang. Universitas Negeri Semarang 
[6] Abidin,, Marzal, J., dan Rohati. 2014. Pengembangan Media Pembelajaran Matematika Interaktif Berbasis Android Untuk Menumbuhkan Motivasi Belajar Anak Disleksia Pada Materi Eksponensial Di Kota Jambi. Edumatika 4(2)

[7] Darusalam, A. (2015). Pengembangan media pembelajaran berbasis web interaktif (blog) untuk meningkatkan motivasi belajar pada mata pelajaran pemasaran online sub kompetensi dasar merancang website (studi pada siswa kelas X tata niaga SMK Negeri 2 Nganjuk). Jurnal Pendidikan Tata Biaga (JPTN) 3 (2)

[8] Purnomo, E.A, Rohman, A, dan Budiharto. 2015. Efektivitas Penerapan Model Pembelajaran Project Based Learning (PBL) Berbasis Maple Matakuliah Kalkulus Lanjut II. Jurnal Karya Pendidikan Matematika. 2 (2) https://jurnal.unimus.ac.id/index.php/JPMat/article/view/1700/1749

[9] Thiagarajan, S., D. S. Semmel, and M. I. Semmel. 1974. Instructional Development for Training Teachers of Exceptional Children, A Source Book. Blomington: Indiana University

[10] Mawarsari, V.D dan Purnomo, E.A. 2016. Pemanfaatan Software Geogebra Berbantuan E Learning Dalam Pembelajaran Geometri. Jurnal Karya Pendidikan Matematika (JKPM). 4 (2). https://jurnal.unimus.ac.id/index.php/JPMat/article/view/3166/3052

[11] Yen, H.C., Tuan, H.L., dan Liao, C.H. 2011. "Investigating the influence of Motivation on Students" Conceptual Learning Outcomes In Web-Basedvs. Classroom-Based Science Teaching Contexts". Research Science Education, 41:211-224.

[12] Setyadi, D., dan Abd. Qohar. 2017. Pengembangan Media Pembelajaran Berbasis Web pada Materi Barisan dan Deret. Kreano 8 (1).

[13] Varma, K. dan Linn, Marcia C. 2011. "Using Interactive Technology to Support Students' Understanding of The Greenhouse Effect and Global Warming". Journal of Science Educational Technology.

[14] Flynn, A. B. 2012. "Development of An Online, Postclass Question Method and Its Integration with Teaching Strategies". Journal of Chemical Education, 89. 